\title{
Konseling sebagai Upaya Meningkatkan Kepemimpinan Transformasional
}

\section{Counseling as an Effort to Improve Transformational Leadership}

\author{
Nur Pratiwi Noviati* \\ Fakultas Psikologi dan IImu Sosial Budaya UII, Yogyakarta 55584 \\ Sri Hartati \\ Fakultas Psikologi Universitas Gadjah Mada, Yogyakarta 55281
}

Diterima 10 April 2009 / Disetujui 25 Mei 2009

\begin{abstract}
This research is aimed to analyze the effectiveness of counseling as an effort to improve transformational leadership in managing organizational change. The research subject were 4 individuals whose transformational leadership style may be improved. Research subject was selected randomly from 7 heads of division in FTI UII. Selected subjects were divided into 2 groups (2 subjects in experiment group, and 2 subjects in control group). Experiment group was provided with counseling treatment directed to be able to understand transformational leadership concept and applying it in working site applying. Measurement was done before treatment using 33 statements on transformational leadership from Multifactor Leadership Questionnaire (MLQ) and 2 months after treatment using $M L Q$ and transformational behaviour checklist. The data obtained was compared and analyzed using Chi-Square test. In addition, the result of counseling and working sheet were derined from implementation and are also used in measuring effectiveness of counseling. Qualitative analysis was stressed in this research. The result of the research indicated that counseling can improve individual transformational leadership.
\end{abstract}

Keywords: Transformational, Leadership, Counseling

Pada akhir abad ke-20 dan memasuki abad ke-21 berbagai jenis organisasi (termasuk organisasi niaga, organisasi di lingkungan pendidikan, organisasi di lingkungan pemerintah, organisasi sosial yang bersifat nirlaba) akan menghadapi perubahan dengan variasi, intensitas dan cakupan yang belum pernah dialami sebelumnya. Tuntutan untuk melakukan perubahan dapat timbul dari dua sumber, yaitu dari dalam organisasi itu sendiri dan dari lingkungannya. Ketika menghadapi masa depan, berbagai jenis organisasi tersebut hanya

\footnotetext{
- Penulis Korespondensi :

Teip. (0274) 550435, HP : 08122559725, Email : nur_pratiwi_noviat@yahoo.com
} 
akan berkembang dan maju apabila cepat tanggap terhadap perubahan yang pasti akan terjadi (Siagian, 2004).

Organisasi yang sedang mengalami perubahan membutuhkan strategi yang tepat untuk mengelola perubahan tersebut. Salah satu hal yang memegang peran penting dalam mengelola perubahan adalah pemimpin. Bibeault's (Landrum, Howell dan Paris, 2000) mengatakan bahwa kepemimpinan dan strategi memiliki hubungan yang kuat, kepemimpinan merupakan faktor penting untuk menyukseskan strategi perubahan.

Model kepemimpinan merupakan alat untuk mengelola perubahan organisasi (Touron, 2005). Burn (Landrum, Howell \& Paris, 2000) melihat bahwa kepemimpinan transformasional memiliki sifat dan perilaku yang dibutuhkan dalam memulai perubahan. Daft (1999) menganggap bahwa kepemimpinan transformasional memiliki kemampuan untuk memimpin perubahan dalam visi, strategi dan budaya organisasi, sebaik memunculkan inovasi dalam produk dan teknologi. Simic (1998) menyatakan bahwa manajemen perubahan dapat berjalan sukses jika didukung oleh kemampuan transformasional yang tepat (karisma, konsiderasi individu, stimulasi intelektual dan motivasi inspirasional) dan atribut transformasional yang tepat (kreativitas, orientasi pada tim, penghargaan pada orang lain, mengajar, bertanggungjawab, pengakuan).

Perilaku transformasional terdiri dari empat dimensi, yaitu pengaruh ideal, motivasi inspirasional, stimulasi intelektual dan pertimbangan individu (Avolio \& Bass, 1998; Avolio. Bass, Jung \& Berson, 2003; Hendel, Fish \& Galon, 2005; Howell \& Hall-Marenda, 1999; Kelloway; Kelloway \& Barling, 2000; Palmer, Walls, Burgess \& Stough, 2001; Simic, 1998; Yukl, 2006). Keempat dimensi perilaku transformasional adalah (a) pengaruh ideal, memberi makna pada apa yang diharapkan pemimpin dari pengikutnya. Pemimpin menimbulkan rasa kagum, rasa percaya dan rasa hormat para pengikut dengan melakukan hal yang benar daripada memastikan mereka melakukan hal yang benar. Pemimpin menyediakan waktu guna membuat keputusan yang lebih transparan dan konsisten, (b) motivasi inspirasional, membangkitkan semangat kerja secara inspirasional (mendorong karyawan untuk meningkatkan kinerja melebihi dugaan mereka sendiri), bukan melalui pertimbangan kalkulatif. Diantara contoh perilaku tersebut adalah meyakinkan pengikut bahwa pengembangan karir mereka di lingkungan kerja sekarang adalah pilihan terbaik; mengartikulasikan dengan baik dan memberi makna pada kondisi masa depan yang dicitacitakan bersama; memberi semangat pengikut untuk mencapai hasil-hasil istimewa baik dalam bentuk kinerja maupun perkembangan diri sendiri, (c) stimulasi intelektual, meningkatkan kesadaran belajar dan berbagi pengetahuan di antara para pengikut. 
Kemampuan pemimpin membuat karyawannya berpikir mengenai masalah yang berkaitan dengan pekerjaan dengan jalan baru, dan (d) pertimbangan individu, mempedulikan kesejahteraan psiko-sosial para pengikut. Selain itu, dimensi ini juga meliputi memperlakukan karyawan sebagai individu dengan mengasihani, menghargai dan merespon kebutuhan mereka, serta mengakui dan merayakan keberhasilan mereka.

Pemimpin memiliki peran penting pada tiap tahap perubahan, hal tersebut sejalan dengan yang disampaikan oleh Kotter (dalam Daft, 1999; Wibowo, 2006) yang menyatakan bahwa pemimpin memiliki peran dalam delapan tahap perubahan organisasi seperti yang tertera pada gambar berikut.

\section{Gambar 1. Peran Pemimpin dalam Tiap Tahap Perubahan Organisasi (Daft, 1999)}

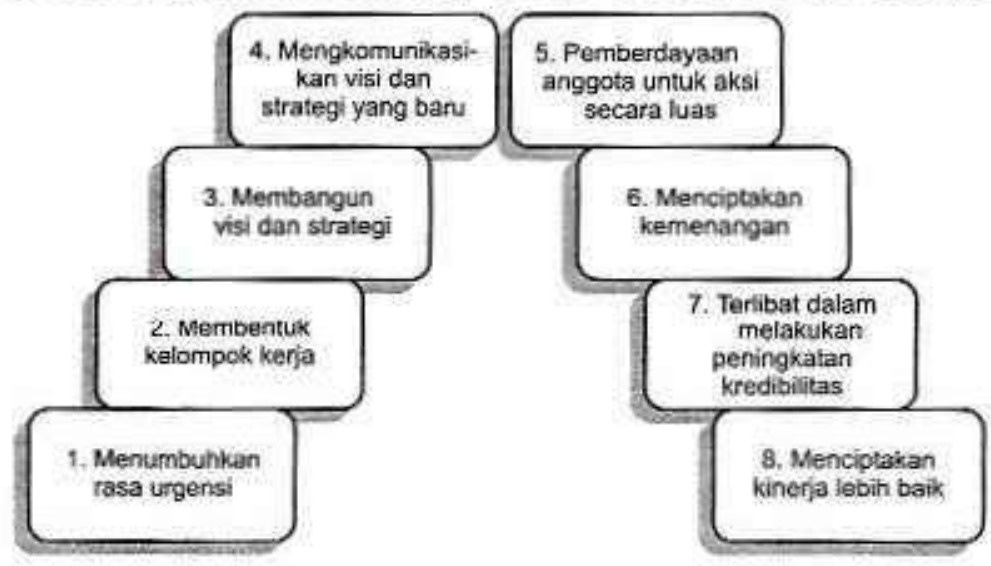

Tahap pertama, organisasi perlu dicairkan dengan cara menciptakan alasan mengapa perubahan perlu dilakukan. Tahap kedua, pemimpin membentuk kelompok kerja yang memiliki kekuasaan cukup untuk memimpin perubahan serta mengembangkan rasa kerja sama diantara anggotanya. Tahap ketiga, pemimpin terlibat dalam menciptakan visi untuk mengarahkan usaha perubahan dan mengembangkan strategi untuk mencapa visi yang telah ditetapkan. Tahap keempat, pemimpin perlu mengkomunikasikan secara terus-menerus visi dan strategi yang baru setiap ada kesempatan agar dipahami dan mendapatkan dukungan. Tahap kelima, pemimpin perlu memberdayakan anggota organisasi dengan mendorong keberanian mereka untuk melakukan tindakan kreatif, mengambil risiko dan melakukan tindakan non-tradisional. Tahap keenam, pemimpin perlu segera merencanakan perbaikan kinerja untuk menciptakan kemenangan, serta mengenal dan menghargai karyawan yang memungkinkan kemenangan. Tahap ketujuh, permimpin turut terlibat dalam melakukan peningkatan kredibilitas dapat mengubah semua sistem. struktur dan kebijakan 
yang tidak sesuai dengan perubahan. Tahap kedelapan, pemimpin memberikan makna hubungan yang lebih antara perilaku baru dan keberhasilan organisasi, serta melakukan pengembangan sarana untukmendukung suksesi dan kepemimpinan.

Organisasi yang sedang melakukan perubahan perlu membentuk para pemimpinnya menjadi pemimpin yang transformasional pernimpin yang memfokuskan pada upaya memunculkan potensi para anggota organisasi secara maksimal dalam suatu lingkungan kerja yang penuh tantangan (Yukl, 2006 ; Daft, 1999), yaitu dengan cara meningkatkan dan mengembangkan kepemimpinan transformasionalnya. Oleh karena itu peneliti mencoba menyusun suatu perlakuan yang di dalamnya terdapat transfer pengetahuan, pemberian umpan balik serta rencana aksi individu, dan semuanya dikemas dalam satu perlakuan yaitu konseling kepemimpinan transformasional. Hal tersebut sejalan dengan apa yang disampaikan oleh Carroll (1996), bahwa konseling dapat digunakan saat akan melakukan pemberdayaan individu atau kelompok dalam organisasi guna membantu proses perubahan organisasi dan anggotanya.

Proses konseling dilakukan dalam tiga langkah (Egan, 1990), langkah pertama adalah mengenali situasi, langkah kedua adalah mengubah gambaran, dan langkah ketiga adalah mengimplementasikan tindakan. Pendekatan yang digunakan dalam konseling tersebut merupakan integrasi dari pendekatan kognitif dan perilaku. Pendekatan kognitif beranggapan bahwa pemikiran manusia merupakan penyebab dasar dari munculnya permasalahan dan setiap manusia pasti memiliki potensi untuk mengolah pemikiran (Willis, 2004), sedangkan pendekatan perilaku beranggapan bahwa perubahan perilaku dapat terjadi dengan adanya penerapan prinsip-prinsip belajar yang sistematis (Corey, 1999). Dengan demikian dapat dikatakan bahwa pikiran seseorang dapat mempengaruhi tindakan mereka dan tindakan itu akan mempengaruhi bagaimana mereka berpikir (Egan, 1990; Willis, 2004).

Secara sederhana proses konseling tersebut membawa konseli dari kondisi individu yang belum mengembangkan potensi dirinya dan belum mengetahui perilaku tertentu, menjadi individu yang mampu mengembangkan potensi diri serta memahami dan mampu mengaplikasikan perilaku tertentu yang diharapkan. Individu akan melakukan proses belajar aktif selama menjalani konseling. Belajar aktif merupakan pengelolaan perubahan yang efektif untuk mengubah pengetahuan menjadi tindakan yang menghasilikan dalam organisasi (Pawitra \& Chan, 2003).

Berdasarkan pada uraian di atas maka dapat dikatakan bahwa penelitian ini dilakukan guna menguji sejauh mana konseling kepemimpinan transformasional berperan dalam meningkatkan kepemimpinan transformasional individu. Oleh karena itu hipotesis yang 
diajukan dalam penelitian ini adalah konseling kepemimpinan transformasional dapa meningkatkan kepemimpinan transformasional individu.

\section{Metode Penelitian}

\section{Partisipan}

Subjek penelitian. Subjek penelitian adalah individu yang kepemimpinan transformasionalnya masih dapat ditingkatkan lagi. Tempat pelaksanaan penelitian adalah Fakultas Teknologi Industri Universitas Islam Indonesia (FTI UII), karena organisasi tersebut sedang mengalami perubahan internal yang merupakan konsekuensi dari restrukturisasi UII dan mereka sedang melakukan pengelolaan perubahan. Oleh karena itu subjek penelitian dipilih secara acak dari tujuh kepala divisi di FTI UII, yaitu dengan cara mengukur gaya kepemimpinan transformasionainya terlebih dahulu. Setelah didapatkan hasilnya, dipilih empat subjek penelitian berdasarkan Z-score dari rentang -1 sampai dengan 1. Subjek yang telah dipilih tersebut dibagi menjadi dua kelompok yaitu dua orang sebagai kelompok eksperimen dan dua orang sebagai kelompok kontrol. Pemilihan kelompok eksperimen dan kontrol dilakukan dengan cara undian. Hasilnya Kepala Divisi Perkuliahan dan Ujian serta Kepala Divisi Perbekalan dan RT termasuk dalam kelompok eksperimen, sedangkan Kepala Divisi Keuangan dan Kepala Divisi SIM termasuk dalam kelompok kontrol.

Evaluator. Evaluator merupakan subjek yang menjadi sumber data guna pengukuran gaya kepemimpinan transformasional dari subjek penelitian, terdiri dari subordinat masingmasing subjek penelitian.

Konselor. Konselor adalah individu yang terlibat dalam manipulasi penelitian (konseling kepemimpinan transformasional), minimal berlatar belakang pendidikan Profesi Psikologi. Memahami dan menguasai keterampilan konseling, memahami konsep kepemimpinan transformasional serta dapat memahami dengan baik manajemen organisasi.

\section{Rancangan Penelitian}

Penelitian ini menggunakan desain prates-pascates dengan kelompok kontrol (pretest-posttest with control group design), yaitu melakukan pengukuran sebelum dan sesudah pemberian perlakuan pada dua kelompok. Berdasarkan pada desain penelitian tersebut maka pengukuran dilakukan sebelum dan dua bulan sesudah sesi konseling berakhir. Pengukuran dilakukan oleh subordinat dari masing-masing subjek penelitian. 


\section{Pengukuran Data}

Efektivitas konseling diukur melalui gaya kepemimpinan subjek dengan menggunakan 33 pernyataan mengenai kepemimpinan transformasional dari Multifactor Leadership Questionnaire (MLQ) yang disusun oleh Purwanto (2000), serta transformational behavior checklist yang disusun berdasarkan empat dimensi perilaku kepemimpinan transformasional.

Angket kepemimpinan transformasional memiliki reliabilitas sebesar 0.905 , terdiri dari aspek pengaruh ideal, aspek motivasi inspirasional, aspek stimulasi intelektual, dan aspek pertimbangan individu. Gaya kepemimpinan ditunjukkan dengan menggunakan skor penilaian yang bergerak dari satu sampai lima., sedangkan transformational behavior checklist terdiri dari 11 pernyataan aspek pengaruh ideal, tujuh peryataan aspek pertimbangan individu, 11 pernyataan aspek motivasi inspirasional, dan delapan pemyataan aspek stimulasi intelektual.

Selain mengukur gaya kepemimpinan, tingkat pengetahuan mengenai kepemimpinan transformasional juga diukur. Alat ukur pengetahuan kepemimpinan terdiri dari 17 aitem. memiliki reliabilitas sebesar 0.755 yang dihitung dengan menggunakan formula KuderRichardson 20 (KR-20). Indeks diskriminasi aitemnya bergerak dari 0.14-0.57. Indeks kesukaran aitemnya bergerak dari 0,24-0.76. Sedangkan efektivitas distraktornya secara keseluruhan dapat dikatakan cukup efektif.

\section{Intervensi}

Kelompok eksperimen (konseli) mengikuti proses konseling individu dalam beberapa sesi yang jumlah sesinya disesuaikan dengan perkembangan kemampuan konseli. Masingmasing sesi menggunakan waktu kurang lebih 60 menit. Sebelum konseling dimulai, gaya kepemimpinan transformasional mereka diukur terlebih dahulu oleh subordinat dari masingmasing konseli. Hasil pengukuran tersebut dijelaskan dan dibahas bersama dalam sesi konseling (Avolio \& Bass, 1998; Kelloway, Barling \& Weber, 1996; Kelloway, Barling \& Helleur, 2000). Mereka diajak untuk memahami bagaimana pemimpin transformasional itu berperan dalam mengelola perubahan. Sesi konseling diakhiri dengan mengembangkan tujuan spesifik pada masing-masing konseli, yang kemudian direalisasikan dalam perilaku spesifik pada pekerjaan sehari-hari. Proses konseling dilakukan dalam tiga langkah yaitu:

1. Langkah pertama: mengenali situasi. Pada langkah ini konseli diajak untuk mengidentifikasi masalah yang dihadapi konseli sebagai seorang pemimpin, serta kesempatan yang belum dimanfaatkan secara optimal guna mengatasi permasalahan. 
a. Pertama konselor memancing konseli untuk bercerita tentang dirinya selama terlibal dalam organisasi dan lingkungannya sebagai seorang pemimpin. Tujuannya adalah agar konseli mendapatkan gambaran secara jelas dari sudut pandangnya mengenai sosok dirinya sebagai seorang pemimpin.

b. Kemudian konselor menunjukkan hasil pengukuran gaya kepemimpinan transformasional konseli, sembari menjelaskan bagaimana gambaran kepemimpinan yang mereka miliki. Selain itu konselor juga memberikan gambaran mengenai bagaimana perilaku pemimpin transformasional dan peran pemimpin dalam perubahan, dengan cara memancing konseli terlebih dahulu untuk menjelaskannya. Tujuannya adalah agar konseli dapat mengembangkan sudut pandang baru tentang diri dan masalah yang dihadapinya, sehingga mampu menyadari kelemahannya.

c. Selanjutnya konselor memancing konseli untuk mengidentifikasi potensi internal (misal minat dan keterampilan) serta potensi eksternal (misal lingkungan organisasi) yang dapat memberikan pengaruh dalam mengatasi masalah. Setelah itu menentukan prioritas faktor mana yang lebih berpengaruh dalam proses penyelesaian masalah.

2. Langkah kedua: mengubah gambaran. Pada langkah ini konseli akan menentukan tujuan dengan menyusun apa saja yang ingin dicapainya. Tujuan tersebut disusun berdasarkan pemahaman konseli terhadap kondisi atau masalah yang sedang dihadapinya, serta pemahamannya mengenai kepemimpinan transformasional.

a. Pada tahap ini konselur memancing konseli untuk wengidentifikasi permasaiahan yang muncul di divisi atau lingkungannya dan menggunakannya sebagai isu yang dapat membantu memperluas sudut pandang konseli dan mengindikasikan adanya solusi permasalahan. Tujuannya adalah agar konseli dapat menentukan kemungkinan yang lebih baik pada masa yang akan datang.

b. Selanjutrya konseli diminta untuk menentukan prioritas hasil yang diharapkan dan konsekuensi yang mungkin muncul dari pilihan sikapnya. Konseli akan menyusun tujuannya sebagai seorang pemimpin dengan mempertimbangkan kelemahan dan potensi yang dimilikinya.

c. Konseli difasilitasi untuk membentuk komitmen mewujudkan tujuan yang telah disusunnya sebagai seorang pemimpin.

3. Langkah ketiga : mengimplementasikan tindakan. Pada langkah ini konseli diajak untuk mengembangkan strategi guna mencapai tujuan.

a. Konseli difasilitasi untuk menyusun langkah-langkah strategis guna mewujudkan 
tujuannya.

b. Kemudian konseli diajak untuk memilih strategi terbaik yang sesuai dengan situasi dan kondisi lingkungan kerja serta sumber daya yang dimiliki organisasinya.

c. Selanjutnya konseli menyusun rencana berupa langkah operasional yang dilakukan untuk mengimplementasikan tindakan sebagai seorang pemimpin transformasional yang berperan dalam mengelola perubahan. Rencana yang berupa perilaku spesifik tersebut disusun untuk jangka waktu dua bulan. Jika konseli telah yakin terhadap rencana yang disusunnya, maka sesi konseling pun dapat diakhiri.

Segala sesuatu yang terkait dengan pelaksanaan konseling (seperti prosedur pelaksanaan konseling, proses belajar dalam konseling, materi dan form pelaksanaan konseling) diatur dan dijelaskan dalam Panduan Pelaksanaan Konseling Kepemimpinan Transformasional.

\section{Metode Analisis Data}

Selanjutnya hasil pengukuran tersebut diolah terlebih dahulu. Analisis dilakukan dengan melihat perbandingan tingkat kepemimpinan transformasional pada masing-masing kelompok penelitian antara sebelum dan setelah diberi perlakuan, serta menggunakan analisis Kai Kuadrat (Chi-square Test).

\section{Hasil Penelitian}

Pengukuran efektivitas konseling dalam meningkatkan kepemimpinan transformasional subjek dilakukan dengan membandingkan perolehan nilai rerata kepemimpinan transformasional pada masing-masing kelompok penelitian antara sebelum dan setelah diberi perlakuan. Selanjutnya akan dilakıkan analisis isi pada pernyataan angket kepemimpinan transformasional yang telah direspon oleh subordinat masing-masing subjek penelitian. Sedangkan data hasil (transformational behavior check-list) digunakan sebagai analisis tambahan untuk melihat perbedaan kepemimpinan transformasional antar kelompok kontrol dan eksperimen setelah diberi perlakuan. Selain itu hasil pengukuran tingkat pengetahuan kepemimpinan transformasional pada kelompok eksperimen serta kontrol antara sebelum dan sesudah diberi per akuan juga dilihat perbandingan reratanya.

Nilai rerata yang didapatkan pada masing-masing menunjukkan bahwa divisi SIM mengalami perubahan sebesar 12 poin, divisi keuangan mengalami perubahan sebesar satu poin, divisi perbekalan mengalami perubahan sebesar 12.25 dan divisi perkuliahan mengalami perubahan sebesar 19 poin. Berikut ini merupakan gambaran nilai rerata yang 
terdapat pada masing-masing divisi sebelum dan setelah diberi perlakuan.

Gambar 2. Grafik Tingkat Kepemimpinan Transformasional Pada

Masing-masing Divisi Sebelum dan Sesudah Diberi Perlakuan

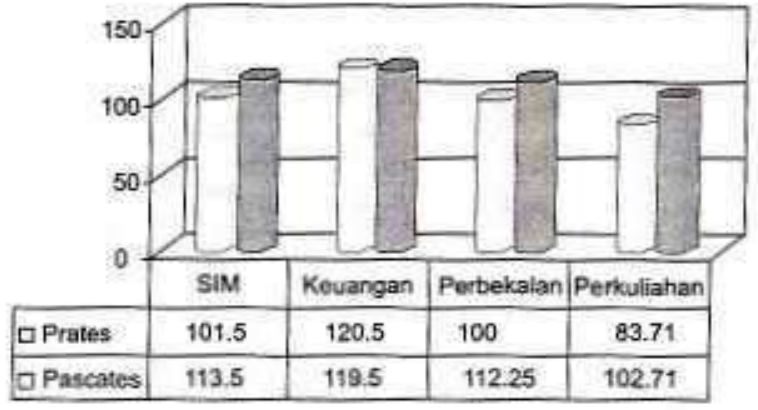

Berdasarkan pada respon yang telah diberikan oleh subordinat masing-masing divisi pada angket kepemimpinan transformasional didapatkan beberapa gambaran mengenai perilaku kepemimpinan transformasional subjek penelitian yang dinilai tidak pernah dilakukan. Pada Divisi SIM sebelum diberi perlakuan terdapat empat item yang diberi respon atasan dianggap tidak pernah menunjukkan perilaku tersebut, dan pada saat pascates terdapat dua item yang diberi respon atasan dianggap tidak pernah menunjukkan perilaku tersebut. Pada Divisi Keuangan sebelum diberi perlakuan terdapat empat item yang diberi respon atasan dianggap tidak pernah menunjukkan perilaku tersebut, dan pada saat pascates tidak terdapat pemyataan yang diberi respon atasan dianggap tidak pernah menunjukkan perilaku tertentu. Pada Divisi Perbekalan \& Rt sebelum diberi perlakuan terdapat 13 item yang diberi respon atasan dianggap tidak pernah menunjukkan perilaku tersebut, dan setelah diberi perlakuan terdapat sembilan item yang diberi respon atasan dianggap tidak pernah menunjukkan perilaku tersebut. Kemudian pada Divisi Perkuliahan dan Ujian sebelum diberi perlakuan terdapat 29 item yang diberi respon atasan dianggap tidak pernah menunjukkan perilaku tersebut, dan setelah diberi perlakuan terdapat empat item yang diberi respon atasan dianggap tidak pernah menunjukkan perilaku tersebut.

Selanjutnya hasil analisis dari daftar perilaku transformatif menunjukkan nilai Kai Kuadrat=22.5, jika db=1 maka taraf signifikansi $5 \%$ dan $1 \%$ adalah sebesar 3.841 dan 6.635 . Jadi nilai Kai Kuadrat tersebut nilainya lebih besar daripada nilai tabel, baik untuk taraf signifikansi $5 \%$ maupun $1 \%$. Hal tersebut menunjukkan bahwa terdapat perbedaan perilaku kepemimpinan transformasional pada kelompok kontrol dan kelompok eksperimen.

Hasil pengukuran tingkat pengetahuan kepemimpinan transformasional pada kelompok eksperimen serta kontrol antara sebelum dan sesudah diberi perlakuan 
menunjukkan bahwa kelompok kontrol mengalami perubahan 1.5 poin dan kelompok eksperimen mengalami perubahan sebesar 7.5 poin. Berikut ini merupakan gambaran nilai rerata yang terdapat pada subjek penelitian sebelum dan setelah diberi perlakuan.

Gambar 3. Grafik Skor Tingkat Pengetahuan Kepemimpinan Transformasional Pada Kelompok Eksperimen dan kontrol Sebelum dar Sesudah Diberi Perlakuan

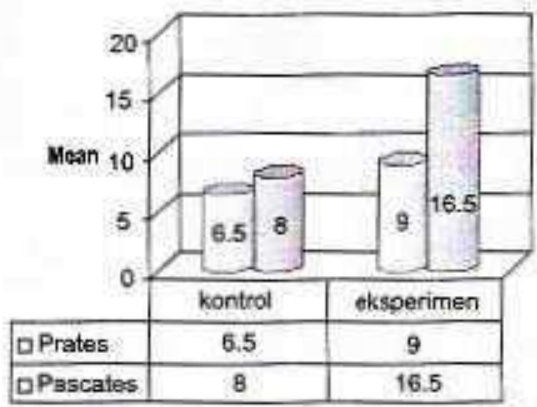

Kelompok eksperimen mengikuti proses konseling individu dalam beberapa sesi yang jumlah sesinya berbeda, karena disesuaikan dengan perkembangan kemampuan konseli. Kepala Divisi Perkuliahan dan ujian mengikuti proses konseling sebanyak lima sesi, sedangkan Kepala Divisi Perbekalan dan Rt sebaryak tiga sesi. Hal tersebut terjadi karena masing-rnasing individu mengalami perkembangan yang berbeda selama mengikuti proses konseling, namun keduanya telah sama-sama menyelesaikan proses konseling yang dijalani.

Masing-masing subjek kelompok eksperimen memiliki hasil konseling, yaitu berupa rencana aksi individu yang terdiri dari tujuan, langkah strategis dan aktivitas yang dilakukan. Hasil konseling tersebut dilaksanakan oleh subjek dalam jangka waktu dua bulan. Pada pelaksanaan hasil konseling ini Kepala Divisi Perbekalan \& Rt mengundurkan diri dari proses penelitian, sehingga hanya Kepala Divisi Perkuliahan \& Ujian yang melaksanakan. Proses pelaksanaan hasil konseling dikontrol dengan menggunakan Catatan Pelaksanaan Aktivitas RencanaAksi sertalembar kerja yang dihasilkan.

\section{Pembahasan}

Permasalahan utama yang hendak dikaji adalah mengetahui sejauh mana konseling kepemimpinan transformasional berperan dalam meningkatkan kepemimpinan transformasional individu. Berdasarkan hasil penelitian diketahui bahwa pada divis Perkuliahan dan Ujian mengalami peningkatan poin kepemimpinan transformasional lebih banyak dibandingkan dengan divisi lain setelah dikenai perlakuan. Kenaikan tersebut juga dapat didukung oleh hasil tes pengetahuan yang menunjukkan bahwa terdapat peningkatar 
pengetahuan kepemimpinan transformasional pada kelompok eksperimen setelah diberi perlakuan. Hal ini sejalan dengan pendapat Kelloway, Barling dan Helleur (2000) yang menyatakan bahwa konseling cenderung dapat meningkatkan kepemimpinan transformasional. Meskipun demikian, analisis kualitatif lebih ditekankan pada penelitian ini.

Periakuan konseling dapat dianggap cukup efektif dalam meningkatkan kepemimpinan transformasional karena di dalamnya terdapat rencana spesifik yang disusun berdasarkan pada konsep kepemimpinan transformasional dan akan dilaksanakan oleh individu (Kelloway \& Barling, 2000). Hal tersebut dapat dilihat pada hasil konseling masingmasing subjek menunjukkan bahwa rencana aksi yang mereka susun telah sesuai dengan konsep kepemimpinan transformasional. Misalnya subjek Kepala Divisi Perkuliahan dan Ujian pada aktivitas akan melaksanakan umpan balik secara tertulis yang berbunyi "Pekerjaan Anda selama ini sudah baik" dan secara lisan "Nah itu betul, perlu dipertahankan". Kalimat-kalimat yang akan disampaikan tersebut adalah salah satu upaya individu dalam mewujudkan perilaku motivasi inspirasional, karena hal tersebut merupakan tindakan kepemimpinan yang dianggap dapat meningkatkan rasa keyakinan diri (self-efficacy) karyawan dan menginspirasi individu untuk mencoba lebih giat (Kelloway \& Barling, 2000). Sedangkan pada kalimat yang berbunyi "Apakah ada hambatan? Kalau ada tolong diceritakan", dan "Adakah yang mempunyai pendapat lain?" merupakan salah satu upaya dalam mewujudkan perilaku stimulasi intelektual, karena hal tersebut menunjukkan pemimpin mengajak pikiran karyawan kembali ke dalam konteks kerja yang telah dilakukan dan menstimulus untuk berpikir dengan cara lain (Kelloway \& Barling, 2000).

Selain itu, upaya-upaya yang dilakukan konselor saat melakukan transfer pengetahuan dan memberikan umpan balik pada subjek juga berperan dalam meningkatkan pemahaman mengenai kepemimpinan transformasional. Secara umum upaya yang dilakukan oleh konselor dalam konseling adalah melakukan interpretasi (memberikan penjelasan terhadap berbagai perilaku, perasaan dan pikiran subjek). Tujuannya adalah mendorong eksplorasi diri subjek yang lebih mendalam, serta memberikan perspektif baru untuk pertimbangan dan pemahaman perilaku subjek (Afiatin, Prakosa, Waringah, \& Kusrohmaniah, 1999). Hal tersebut dapat dilihat dalam salah satu contoh kalimat berikut "Salah satu kelebihan bapak adalah mencoba memahami yang bagus, sedang yang tidak bagus bapak tinggal itu suatu kelemahan ya (disetujui konseli). Tidak yang mungkin dia kurang apa tidak dipahami dulu tapi yang 'rak iso tak tinggale'kira-kira begitu? Jadi itu yang akan diperbaiki ya pakya?".

Selanjutnya, pada hasil penelitian Kelloway dan Barling (2000) disampaikan bahwa melakukan perubahan perilaku kecil dan menekankan pada implementasi perubahan perilaku 
tersebut secara terus-menerus sepanjang waktu merupakan salah satu hal yang mendukun terjadinya peningkatan kepemimpinan transformasional. Oleh karena itu perlakua dilanjutkan dengan melaksanakan rencana aksi yang telah disusun oleh individu. Kepala divi Perkuliahan dan Ujian telah berupaya untuk melaksanakannya dalam jangka waktu du bulan. Hal tersebut dapat dilihat pada Catatan Pelaksanaan Aktivitas Rencana Aksi ser lembar kerja yang dihasilkan. Misalnya pada kasus kerusakan alat perkuliahan, subjek telé melakukan umpan balik dengan cara memberikan kesempatan kepada karyawannya untı berusaha memecahkan masalah yang ada. Hal tersebut ditunjukkan dalam kalim "Menurutmu apa yang sebaiknya dilakukan?". Perilaku subjek tersebut menunjukkan bahv ia berupaya mewujudkan perilaku stimulasi intelektual. Sedangkan Kepala Divisi Perbekalk dan RT tidak menjalankan rencana aksi yang telah disusunnya, sehingga peningkati kepemimpinan transformasional individu tidak dapat dilakukan secara optimal. Perbedai hasil yang dicapai oleh Kepala Divisi Perkuliahan dan Ujian dengan Kepala Divisi Perbekal: dan RT dapat juga dilihat pada respon yang diberikan oleh masing-masing subordinatny Pada Kepala Divisi Perkuliahan dan Ujian sebelum diberi perlakuan menunjukkan bahv respon yang menganggap atasan tidak pernah menunjukkan pengaruh ideal sebanyi sembilan respon, respon yang menganggap atasan tidak pernah menunjukkan motivé inspirasional sebanyak 12 respon, respon yang menganggap atasan tidak pern menunjukkan stimulasi intelektual sebanyak 14 respon, dan respon yang menganggap atas: tidak pernah menunjukkan pertimbangan individu sebanyak 16 respon. Sedangkan setel: diberi perlakuan menunjukkan bahwa respon yang menganggap atasan tidak perni menunjukkan pengaruh ideal sebanyak satu respon, respon yang menganggap atasan tid pernah menunjukkan motivasi inspirasional sebanyak satu respon, respon yang mengangg atasan tidak pernah menunjukkan stimulasi intelektual sebanyak satu respon, dan resp yang menganggap atasan tidak pemah menunjukkan pertimbangan individu sebanyak se respon. Kemudian pada Kepala Divisi Perbekalan dan RT sebelum diberi perlaku menunjukkan bahwa respon yang menganggap atasan tidak pernah menunjukkan pengar ideal sebanyak dua respon, respon yang menganggap atasan tidak pernah menunjukk motivasi inspirasional sebanyak lima respon, respon yang menganggap atasan tidak pern menunjukkan stimulasi intelektual sebanyak lima respon, dan respon yang mengangg atasan tidak pernah menunjukkan pertimbangan individu sebanyak dua respon. Sedangk setelah diberi perlakuan menunjukkan bahwa respon yang menganggap atasan tidak pern menunjukkan pengaruh ideal sebaryak satu respon, respon yang menganggap atasan tid pernah menunjukkan motivasi inspirasional sebanyak tiga respon, respon yang mengangg 
atasan tidak pernah menunjukkan stimulasi intelektual sebanyak empat respon, dan respon yang menganggap atasan tidak pernah menunjukkan pertimbangan individu sebanyak dua respon.

Secara keseluruhan dapat dikatakan bahwa individu (Kepala Divisi Perkuliahan dan Ujian) telah melakukan proses belajar aktif pada saat mengikuti konseling dan pelaksanaan hasil konseling. Pada tahap pertama individu telah mengetahui konsep kepemimpinan transformasional sehingga dapat merumuskan kelebihan dan kelemahan yang dimilikinya. Tahap kedua individu telah mengidentifikasi potensi dan menjadikannya bahan pertimbangan dalam menyusun tujuan. Selanjutnya pada tahap tindakan, individu menyusun rencana aksi yang dilengkapi dengan rencana strategi dan aktivitas yang akan dilakukan. Tahap keempat adalah tahap dimana individu mulai menjalankan aktivitas sesuai dengan rencana yang telah disusun olehnya. Harapannya individu akan terus berupaya menerapkan perilaku-perilaku kepemimpinan transformasional secara terus-menerus sehingga dapat sampai pada tahap terakhir, yaitu individu menjadi seorang pemimpin yang transformasional yaitu pemimpin yang selalu memfokuskan pada upaya memunculkan potensi para anggota organisasi secara maksimal dalam suatu lingkungan kerja yang penuh tantangan (Yukl, 2006; Daft, 1999).

Hal lain yang dlanggap juga menyebabkan peningkatan kepemimpinan transformasional pada kelompok eksperimen adalah adanya pelaksanaan penilaian kondite (penilaian yang digunakan sebagai salah satu bahan pertimbangan untuk penetapan jabatan layak dilanjutkan atau dihentikan) serta audit mutu internal. Selama proses pelaksanaan tersebut masing-masing subjek berupaya seoptimal mungkin untuk menunjukkan kinerja yang baik, sehingga peran kepala divisi sebagai pemimpin yang transformasional dapat lebih diasah ketika frekuensi interaksi dengan para stafnya lebih tinggi. Hal tersebut dapat didukung dengan pendapat Yuki (2006) yang menyatakan bahwa kepemimpinan dipengaruhi oleh tiga variabel antara yaitu (1) karakteristik pemimpin, (2) karakteristik pengikut, (3) karakteristik situasi. Ketiga variabel tersebut memiliki hubungan sebab-akibat, karakteristik pemimpin mempengaruhi karakteristik pengikut, dan karakteristik situasi mempengaruhi kedua karakteristik lainnya sampai akhimya ketiga variabel tersebut memberikan pengaruh pada hasil kerja. Jika dilihat berdasar pada hubungan sebab-akibat tersebut maka hubungan antara pelaksanaan penilaian kondite serta audit mutu internal dengan peningkatan kepemimpinan transformasional dapat dilihat dengan jelas pada gambar berikut. 
Gambar 4. Hubungan Sebab Akibat Antar Variabel Pada Kepemimpinan Transformasional

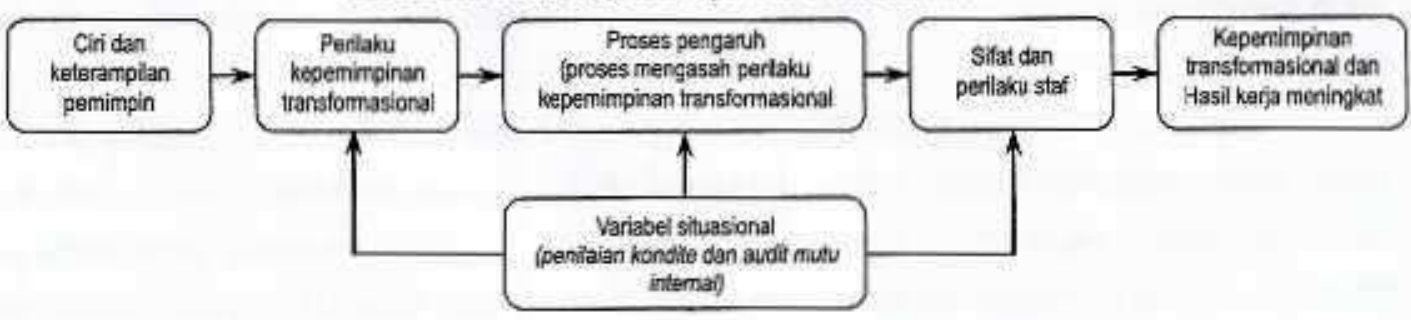

Berdasarkan pada analisis data penelitian dapat dikatakan bahwa konseling kepemimpinan transformasional yang diberikan dapat meningkatkan kepemimpinan transformasional individu. Hal tersebut didukung juga oleh penilaian yang diberikan konselor (sebagai pelaksana desain konseling) yang menyatakan bahwa meningkatkan dan mengembangkan kepemimpinan transformasional dengan menggunakan konseling dapat memberikan kesempatan konselor untuk melakukan intervensi lebih terbuka dan personal konseli menjadi lebih mudah digali, sehingga kesempatan untuk meningkatkan kepemimpinan transformasional menjadi lebih besar.

\section{Simpulan dan Rekomendasi}

Pemimpin yang transformasional merupakan pemimpin yang memfokuskan pada upaya memunculkan potensi para anggota organisasi secara maksimal dalam suatu lingkungan kerja yang penuh tantangan, sehingga dapat mendukung perubahan organisasi. Kepemimpinan transformasional dapat ditingkatkan melalui transfer pengetahuan kepemimpinan transformasional, pemberian umpan balik serta rencana aksi individu, dan semuanya dikemas dalam satu perlakuan yaitu konseling kepemimpinan transformasional.

Selanjutnya, bagi yang tertarik untuk menggunakan desain konseling kepemimpinan transformasional ini sebaiknya memperhatikan beberapa hal yang dapat mempengaruhi perubahan tingkat kepemimpinan transformasional, karena pada desain konseling kepemimpinan transformasional ini masih terdapat kelemahan pada rangkaian materi konseling dan jangka waktu pelaksanaan rencana aksi individu. Kelemahan tersebut antara lain yaitu (1) sebaiknya menyusun materi kepemimpinan transformasional yang bahasanya disesuaikan dengan karakter dan lingkungan kerja individu, jadi tidak hanya berupa konsef teori, (2) sebaiknya pelaksanaan konseling dilakukan pada saat waktu yang tepat agar tidak mengganggu konsentrasi kerja dan konseling dapat berjalan dengan lebih efektif, dan (3) sebaiknya jangka waktu yang digunakan untuk melaksanakan rencana aksi individu tidak 
hanya dua bulan saja, tetapi minimal tiga bulan. Kelloway dan Barling (2000) menyatakan bahwa butuh waktu tiga atau empat bulan untuk dapat menunjukkan perilaku kepemimpinan transformasional secara optimal sehingga benar-benar dapat mengubah persepsi karyawan. Setelah itu sebaiknya dilakukan sesi konseling lagi sebagai sesi tindak lanjut bagi pelaksanaan rencana aksi individu, fungsinya adalah sebagai sesi 'pendorong' guna memperkuat implementasi individu dalam meningkatkan kepemimpinan transformasional. Selain itu untuk kepentingan penelitian sebaiknya konselor tidak memiliki hubungan dengan instansi terkait untuk menghindari terjadinya bias selama proses penelitian, serta menggunakan subjek penelitian yang jumlahnya lebih besar supaya jumlah subjek tidak terlalu sedikit jika dikenai pengolahan data.

\section{Daftar Pustaka}

Avolio, B. J. \& Bass, B., M. 1998. You Can Drag a Horse to Water but You Can't Make it Drink Unless It is Thirsty, The Journal of Leadership Studies, 4, 393-399.

Avolio, B. J., Bass, B., M., Jung, D., I. \& Berson, Y. 2003. Predicting Unit Performance by Assessing Transformational and Transactional Leadership. Journal of Applied Psychology, 88, 207-218.

Carroll, M. 1996. Workplace Counselling A Systematic Approach to Employee Care. London. Thousand Oaks. New Delhi: Sage Publications.

Corey, G. 1999. Teoridan Praktek Konseling dan Psikoterapi. Bandung: PT Refika Aditama.

Daft, R. L. 1999. Leadership Theory and Practice. Orlando: The Dryden Press, Harcourt Brace College Publishers.

Egan, G. 1990. The Skilled Helper a Systematic Approach to Effective Helping. Pacific Grove, California: Brooks/Cole Publishing Company.

Hendel, T., Fish, M. \& Galon, V. 2005. Leadership Style and Choice of Strategy in Conflict Management among Israeli Nurse Managers in General Hospital. Journal of Nursing Management, 13,137-146.

Howell, J., M. \& Hal-Merenda, K., E. 1999. The Ties that Bind: The Impact of Leader-member Exchange, Transformational and Transactional Leadership, and Distance on Predicting Follower Performance. Joumal of Applied Psychology, 84, 680-694.

Kelloway, E. K., Barling, J., \& Weber, T. 1996. Effects of Transformational Leadership Training on Attitudinal and Financial Outcomes: A Field Experiment. Journal of Applied Psychology, 81, 827-832.

Kelloway, E. K. \& Barling, J. 2000. What We Have Learned about Developing Transformational Leaders. Leadership \& Organization Development Journal, 21, 355-362. 
Landrum, N. E., Howell, J.P., \& Paris, L. 2000. Leadership for Strategic Change. Leadership \& Organization Development Journal, 21,150-156.

Palmer, B., Walls, M., Burgess, Z. \& Stough, C. 2001. Emotional Intelligence and Effective Leadership. Leadership \& Organization Development Journat, 22, 5-10.

Pawitra, T., \& Chan, K. C. 2003. From Action Learning to the Teaching Organization: An Experiential Approach. Gadjah Mada International Journal of Business, 5, 131-144.

Purwanto, B. 2000. Penyusunan Skala Kepemimpinan Transformasional dan Transaksional. Laporan Penelitian. Yogyakarta: Fakultas Psikologi UGM.

Siagian, S. P. 2004. Teori Pengembangan Organisasi. Jakarta: Bumi Aksara.

Simic, 1. 1998. Transformational Leadership-the Key to Successful Management of Transformational Organization Changes. The Scientific Journal FACTA UNIVERSITATIS. Series: Economics and Organization, 1, 49-55.

Suryabrata, S. 2000. Metodologi Penelitian. PT. Raja Grafindo Persada. Jakarta.

Touron, M. M. 2005. Permanence and Change: Case Sudy of Changes in Organizational Culture al a Multinational Company. Juumaj of Change Management, 5, 207-219.

Wibowo. 2006. Manajemen Perubahan. Jakarta: PT Raja Grafindo Persada.

Willis, S. S. 2004. Konseling Individual Teoridan Praktek. Bandung:Alfabeta.

Yukt, G. 2006. Leadership in Organization. New Jersey: Pearson Prentice Hall. 